\title{
Refuge
}

Canada's Journal on Refugees

revue canadienne sur les réfugiés

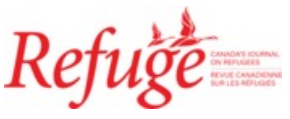

\section{Temporary Protection Regimes and Refugees: What Works? Comparing the Kuwaiti, Bosnian, and Syrian Refugee Protection Regimes}

\section{Jinan Bastaki}

Volume 34, numéro 2, 2018

URI : https://id.erudit.org/iderudit/1055578ar

DOI : https://doi.org/10.7202/1055578ar

Aller au sommaire du numéro

Éditeur(s)

Centre for Refugee Studies, York University

ISSN

0229-5113 (imprimé)

1920-7336 (numérique)

Découvrir la revue

Citer cet article

Bastaki, J. (2018). Temporary Protection Regimes and Refugees: What Works? Comparing the Kuwaiti, Bosnian, and Syrian Refugee Protection Regimes.

Refuge, 34(2), 73-84. https://doi.org/10.7202/1055578ar
Résumé de l'article

Un grand nombre d'États ont riposté aux afflux massifs de réfugiés fuyant la violence ou la guerre généralisée en mettant en place des régimes de protection spéciaux et/ou temporaires. Ces régimes ont été plus ou moins réussis, leur succès dépendant en particulier de la longueur du séjour des réfugiés. Cet article compare les approches étatiques devant trois afflux indépendants de réfugiés - réfugiés koweïtiens dans le Golfe, réfugiés bosniaques en Allemagne, et réfugiés syriens en Turquie - et affirme que des efforts d'harmonisation des mesures de protection temporaire sont souhaitables mais que, étant donné que les situations décrites ont tendance à se prolonger, une plus grande responsabilité doit être assumée entre les états, pour parvenir à une meilleure intégration des réfugiés dans les États hôtes.
Copyright (c) Refuge: Canada’s Journal on Refugees, 2018

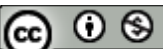

Ce document est protégé par la loi sur le droit d'auteur. L'utilisation des services d’Érudit (y compris la reproduction) est assujettie à sa politique d'utilisation que vous pouvez consulter en ligne. 


\title{
Temporary Protection Regimes and Refugees: What Works? Comparing the Kuwaiti, Bosnian, and Syrian Refugee Protection Regimes
}

\author{
JINAN BASTAKI
}

\begin{abstract}
Many states have responded to mass influxes of refugees fleeing generalized violence and war by setting up ad hoc and/or temporary protection regimes. These regimes have had various degrees of success, depending particularly on the length of stay of the refugees. This article will compare the approach of states to three separate refugee influxesKuwaiti refugees in the Gulf, Bosnian refugees in Germany, and Syrian refugees in Turkey-and will argue that efforts to harmonize temporary protection measures are desirable, but given that these situations tend to be prolonged, there must be greater responsibility sharing between states, in order to lead to greater integration of refugees in the host states.
\end{abstract}

\section{Résumé}

Un grand nombre d'États ont riposté aux afflux massifs de réfugiés fuyant la violence ou la guerre généralisée en mettant en place des régimes de protection spéciaux et/ou temporaires. Ces régimes ont été plus ou moins réussis, leur succès dépendant en particulier de la longueur du séjour des réfugiés. Cet article compare les approches étatiques devant trois afflux indépendants de réfugiés - réfugiés koweïtiens dans le Golfe, réfugiés bosniaques en Allemagne, et réfugiés syriens en Turquie - et affirme que des efforts d'harmonisation des mesures de protection temporaire sont souhaitables mais que, étant donné que les situations décrites ont tendance à se prolonger, une plus grande responsabilité doit être assumée entre les états, pour parvenir à une meilleure intégration des réfugiés dans les États hôtes.

\section{Introduction}

7 he 1951 Convention Relating to the Status of Refugees ("Refugee Convention") has been ratified by over 140 states and provides protections and rights for those who are recognized as refugees under its definition. Who is

Cette œuvre en libre accès fait l'objet d'une licence Creative Commons Attribution-NonCommercial 4.o International License, laquelle autorise l'utilisation, la reproduction et la distribution de l'œuvre sur tout support à des fins non commerciales, pourvu que l'auteur ou les auteurs originaux soient mentionnés et que la publication originale dans Refuge: revue canadienne sur les réfugiés soit citée. 
entitled to the protections provided in the convention can depend on a state's interpretation of the convention's definition of a refugee, and some states can be hesitant to grant refugee status under the convention when there is a mass influx of refugees. ${ }^{1}$ As the Syrian refugee crisis has shown, states have responded in a variety of ways: from providing the full protections of the 1951 Convention, to setting up ad hoc and/ or temporary protection regimes, to outright rejection.

Indeed, prior to the Refugee Convention, in treaties and arrangements concluded under the auspices of the League of Nations, a group or category approach was adopted to manage new refugee situations. The search for a definition was mainly in response to the large-scale Armenian and Jewish refugee crises in the 1900s. ${ }^{2}$ The 1938 Convention on German Refugees, in defining who fell under the provisions of the Convention, stated in article 1: "Persons possessing or having possessed German nationality and not possessing any other nationality who are proved not to enjoy, in law or fact, the protection of the German government."3 The 1951 Refugee Convention, while being geographically and temporally bound at the time, included the definition of a refugee that was individualized as opposed to the previous group approach; in order to be considered a refugee, one had to show a well-founded fear of being persecuted on one of the five grounds enumerated in the convention. ${ }^{4}$ This excludes groups of people who flee generalized violence and war, especially if they have not been individually targeted for persecuted.

However, there was a need to continue with this "group" approach, even after the adoption of the Refugee Convention. In 1957 the UN General Assembly in UNGA resolution 1167 first authorized the UNHCR to assist those who did not come fully within the statutory definition, but whose situation was "such as to be of concern to the international community." Though clearly outside the time frames contained in the 1951 Refugee Convention, the General Assembly also approved the UNHCR's assistance to Algerian refugees in Morocco and Tunisia in 1958, and to the Chinese who fled to Hong Kong in 1959.5 Temporary rights to remain "are supported on the basis that groups of forced migrants have a prima facie claim to being in a 'refugee-like' situation."' Extensions of the UNHCR's mandate do not seem to have altered or expanded the convention's strict definition, because the assistance provided is qualitatively distinct from that given to "refugees" under the convention. ${ }^{7}$ Some regional human rights treaties, such as the 1969 Organization of African Unity's Convention Governing the Specific Aspects of Refugee Problems in Africa, offer a much more expansive definition of a refugee, including "every person who, owing to external aggression, occupation, foreign domination or events seriously disturbing public ... is compelled to leave his place of habitual residence in order to seek refuge in another place." ${ }^{8}$ Indeed,
Ethiopia and Uganda, both states parties to the convention, have adopted a generally open-door policy towards refugees and granted them prima facie refugee recognition. ${ }^{9}$

As the affliction of war has not left, some states have also adopted formal or informal temporary protection measures in response to influxes of refugees in modern times. ${ }^{10}$ There is great need for this, as some countries have not ratified the 1951 Refugee Convention or regional treaties relating to refugees, and others have been reluctant to apply the full protections of the Refugee Convention to large numbers of refugees; indeed, temporary protection measures may encourage otherwise apprehensive states to take in larger numbers of refugees.

However, these ad hoc protection regimes have had varying degrees of success, prompting the question, What works? And what factors contribute to the success or failure of these mechanisms? This article will compare the approach of states to three separate and very different refugee influxesKuwaiti refugees in the Gulf, Bosnian refugees in Germany, and Syrian refugees in Turkey. These examples were chosen as they present varied ways-both formal and informal-of implementing a temporary protection regime and include both positive and negative aspects. Moreover, the case of Kuwaiti refugees has seldom been looked at in the literature. Thus, these cases may help provide suggestions for what can be implemented in the future, and what should be avoided, considering that mass influxes of people cannot be said to be a temporary phenomenon. While adopting minimum standards for states is desirable, issues arise when temporary situations are prolonged. In these cases, there must not only be harmonization of standards for minimum protection, but provisions for greater responsibility sharing between states, as well as greater freedoms for refugees, which will be detailed in the article.

\section{What Is Temporary Protection? And What Can Be Considered a "Successful" Temporary Protection Regime?}

There are several differences between temporary protection and the granting of refugee status. In order to qualify as a refugee under the convention, refugee status determination (RSD) would have to take place in order to ensure that the asylum seeker fulfills the refugee definition, which is usually a lengthy process. Moreover, while the definition may apply to groups of people who fit the convention's definition, it becomes much more difficult in situations of mass influx of refugees. ${ }^{11}$ Hence it becomes easier to apply temporary protection to the entire group. Although not stated explicitly, the domestic policies of many states equate recognition as a refugee under the 1951 Refugee Convention with a right to permanent residence. ${ }^{12}$ 
As a policy, "temporary protection" is more difficult to define, because it can involve and has involved legal and administrative changes in different countries that have adopted such measures and has also evolved in diverse ways. ${ }^{13}$ Nevertheless, there are some common features. Under the UNHCR's guidelines, temporary protection "would be based on categories, groups or scenarios, allowing for a flexible and immediate response to ... [a] crisis." ${ }^{14}$ Indeed, temporary protection serves as "a short-term strategy to secure the immediate physical safety of refugees." 15 Temporary protection is usually also limited in time, ${ }^{16}$ although, as we will see with the example of Kuwaiti refugees in the Gulf and Syrian refugees in Turkey, time limits may not always be set. Other common features of temporary protection include the expectation-and occasional enforcement-of repatriation once it is safe enough to return. ${ }^{17}$ However, according to the UNHCR's guidelines, "in cases of extended stay, or where transition to solutions is delayed, the standards of treatment would need to be gradually improved." 18

Because temporary protection has been applied in very different ways, depending on the country, for the purposes of this article, temporary protection will have the following basic features: (1) permission to stay (2) for mass influxes of people (3) who have crossed an international border (4) fleeing generalized violence or war (5) for a certain period of time (whether stated explicitly or not) ${ }^{19}$ and (6) under arrangements outside of the 1951 Convention for those countries that have ratified it.

Furthermore, a successful temporary protection regime must also be defined. In essence, any response should ensure "full respect for international law and international human rights law" 20 as affirmed in the 2016 New York Declaration for Refugees and Migrants. Moreover, as also suggested by Ineli-Ciger, not only must temporary protection in particular not undermine customary and treaty-based human rights norms, these provisions should not undermine the 1951 Convention in states that are party to the convention. ${ }^{21}$ Moreover, as suggested by the UNHCR's Guidelines, the longer the stay, the greater the allowances that should be extended to the recipients of temporary protection, such as the permission to work, freedom of movement within the country, and the ability to pursue an education. This will help to avoid exploitation, as we will see that difficulties in working for Syrians in Turkey has led to exploitation, and increase self-sufficiency of refugees. This aids in protecting the dignity of refugees, as well as helping to pave the way to more durable solutions.

\section{Kuwaiti Refugees in the Gulf (1990-1991)}

Yemen is the only country in the Arabian Peninsula that has ratified the 1951 Refugee Convention, and Iraq had passed legislation to regulate the status of Palestinian refugees that sought refuge in Iraq in $1948 .{ }^{22}$ Yet the countries that make up the Gulf Cooperation Council (GCC) - Bahrain, Kuwait, Oman, Qatar, Saudi Arabia, and the United Arab Emirateshave not passed any formal refugee laws. ${ }^{23}$ Indeed, for this reason, it is difficult to know how many de facto refugees reside or have been granted leave to stay in these states under alternative arrangements, such as residency or work visas. ${ }^{24}$

In August 1990, Iraq's Saddam Hussein invaded the neighbouring country of Kuwait. This caused the fleeing of hundreds of thousands of people who were living in Kuwait, both citizens and residents, such as Iraqis and Palestinians, ${ }^{25}$ as well as Bidoon (stateless Kuwaitis). More than 1.5 million people fled Iraq, Kuwait, and other Gulf countries, including some 700,000 Egyptians, 250,000 Palestinians or Jordanians, ${ }^{26}$ and more than 350,000 Asians, most of them from India, Sri Lanka, Pakistan, Bangladesh, and the Philippines. ${ }^{27}$ Between 300,000 and 400,000 Kuwaitis became refugees, ${ }^{28}$ mostly in the neighbouring countries. The focus here will be on the treatment of Kuwaitis, since they had the benefit of being allowed to stay within the borders of neighbouring Gulf states.

At least 200,000 of the Kuwaiti refugees sought refuge in Saudi Arabia, and the Saudi Kingdom sheltered the refugees in hotels and apartments, as well as provided food for them. ${ }^{29}$ By late September 1990, approximately 35,000 Kuwaitis had fled to the UAE, who provided them with US $\$ 500$ to begin their lives, as well as free housing, free schooling, and free health care. ${ }^{30}$ Smaller numbers fled to Bahrain and Qatar. ${ }^{31}$ It is also estimated that 40,000 Kuwaiti refugees took refuge in Iran, with the Kuwaiti government-in-exile setting up special bureaus in three Iranian cities to look after the financial needs of their citizens. ${ }^{32}$

This "temporary regime" for Kuwaiti refugees does not appear to have been formalized, nor do there appear to have been laws or regulations passed to delineate the rights of Kuwaitis fleeing to Gulf countries, or minimum standards of treatment. Seeking refuge, however, was made easier by the fact that Kuwaiti citizens, like other Gulf nationals, were and are allowed visa-free travel within the GCC, and freedom to work there. ${ }^{33}$ However, it appears that few Kuwaitis secured jobs, because it was unclear to employers whether they could depend on Kuwaitis to remain in the countries of refuge for the long term. ${ }^{34}$ Additionally, as shown above, the governments of the GCC countries provided generous assistance to these refugees, which made their de facto status different from that of other Gulf nationals. Moreover, it was intended to be temporary. Hessa al-Ossaify, the UAE information minister at the time, responded to the question of the generosity of the UAE towards the Kuwaiti refugees: "We know they [the Kuwaitis] will be our guests for only a short time and we want to help, to show that they are our family." 35 Furthermore, the Gulf states did not shoulder the financial responsibility 
themselves; the emir of Kuwait paid around US $\$ 500$ million a month to sustain the Kuwaiti refugee population, ${ }^{36}$ many of whom were students without a source of income; 37 indeed, the government-in-exile had announced in September 1990 that it would provide monthly allowances of up to U $\$ 320$ for its citizens living in exile. ${ }^{38}$

After the liberation of Kuwait in February 1991, most Kuwaiti refugees returned to their homes. 39 The return of the refugees was voluntary, with no Gulf state enforcing mandatory returns. However, it is unclear when the provision of free housing, schooling, and health care was ceased or reduced, if indeed it was, since most Kuwaitis had wanted to return home to rebuild their country. ${ }^{40}$

\section{Bosnian Refugees in Germany (1992-1995)}

The states that make up the European Union have all ratified the 1951 Refugee Convention, and some even have formal provisions for other forms of protection. Moreover, European Union Directive 2001/55/EC on Minimum Standards for Giving Temporary Protection ${ }^{41}$ provides for "a procedure of exceptional character" that gives "immediate and temporary protection." In order to encourage return, status under the directive continues for one year and may be renewable for up to three years. ${ }^{42}$ However, it should be mentioned that the directive has not been implemented for a variety of reasons. 43

Starting in 1992, shortly after Bosnia's referendum for independence, Serbian forces from the former Yugoslavia began a campaign of war and ethnic cleansing, resulting in some 500,000 refugees from Bosnia and Herzegovina being displaced to every member state of the European Unionand some non-member states. ${ }^{4}$ These states responded by implementing temporary protection measures and, at least initially, "avoiding grants of durable asylum." 45 Temporary protection was set up partly because the arrival of Bosnians was impossible to stop, and partly in response to appeals by the UNHCR and human rights organizations. ${ }^{46}$ The duration of these temporary protection regimes was to be subject to the satisfaction of certain "benchmarks" contained in the Repatriation Plan 47 of the UNHCR. ${ }^{48}$

Germany had the largest Bosnian refugee population of $320,000,49$ so their policies will be the main focus here. Moreover, in most countries where Bosnians fled, they were eventually granted permanent residence rights ${ }^{50}$ - except for Germany. For example, Sweden, Norway, and Finland granted the majority of Bosnians permanent residence permits on humanitarian grounds, while Denmark amended its initial temporary protection regulations to enable all Bosnians who had been resident in Denmark for two years to be given the same rights as other refugees; they eventually received permanent residence permits. ${ }^{51}$ On the other hand, Germany had not implemented any plans enabling Bosnians to apply to a more permanent status. ${ }^{52}$ Furthermore, by the end of 1996, Germany was the only European state to have initiated forced repatriation. 53

Temporary protection for persons from Bosnia was based on a 22 May 1992 decision of the ministers of the interior and the federal government, which set out the principles for admission of persons from Bosnia Herzegovina and enacted a ban on the deportation of these persons to their country. The majority of Bosnians were given two main types of temporary permits, the Duldung (toleration permit) and Aufenthaltsbefugnis (short-term residence permit).54 The Aufenthaltsbefugnis-which was valid for one or two years-was given to ex-detainees and other vulnerable persons, as well as to medical evacuees. ${ }^{55}$ All other Bosnians were given the Duldung - which had to be renewed every six months and could theoretically be renewed indefinitely ${ }^{56}$ - and enabled them to stay in Germany until return/deportation was possible. ${ }^{57}$

Holders of the Aufenthaltsbefugnis were in principle entitled to social aid on the same basis as German nationals, while persons with the Duldung fell in some federal states under the same regime applied to asylum seekers; this meant that assistance could be provided only in kind while a monetary stipend was limited to DM8o per month per person..$^{8}$ After three months, those under temporary protection had access to schools at the primary and secondary level. Holders of either permit were allowed to work if no German or EU national could be employed. The rights afforded to holders of these permits are fewer than the rights enshrined under the Refugee Convention.59

The General Framework Agreement for Peace in Bosnia and Herzegovina was signed on 14 December 1995 and brought a formal end to the war. The UNHCR's Repatriation Plan was adopted on 8 March 1996 and contained minimum standards for voluntary repatriation. By October 1996, Germany insisted that temporary protection had to end and started forced repatriation. ${ }^{60}$ According to UNHCR, around 100,000 Bosnians were repatriated from Germany in 1997, ${ }^{61}$ and by March 2000 only 37,000 Bosnians remained in Germany, many of them who had suffered traumatic ordeals during the war. ${ }^{62}$ Over 92 per cent of the Bosnians who returned between 1997 and 1999 were from Germany. 63 The return of the majority of Bosnians was despite the fact that, particularly in the years immediately following the official end of the war, the minimum conditions for repatriation - that the refugees could return freely to their homes and under conditions of safety-were not fulfilled. ${ }^{64}$

\section{Syrian Refugees in Turkey (2011-Present)}

Between 1934 and 2006, Turkey's Law No. 2510 on Settlement regulated the formal settlement of foreigners in Turkey, and from 1994 to 2014, Regulation No. 1994/6169. ${ }^{65}$ Article 3 of 
Law No. 2510 defined refugees as those who came to Turkey for compelling reasons without the intention of permanent settlement; however, should they subsequently want to settle, article 4 bars "those who are not attached to Turkish culture" from settling permanently. ${ }^{66}$ Law No. 5543 of 2006, which replaced Law No. 2510 on Settlement, did not change this admission policy. According to article 4, those who are not of Turkish descent and culture are not eligible for settlement. Turkey is also party to the 1951 Convention and its 1967 Protocol, but it made a reservation to the 1967 Protocol that it would not remove the geographical limitation. This means that Syrian refugees, by virtue of not being from Europe, are not eligible to apply for refugee status under the 1951 Convention in Turkey. However, under the Law on Foreigners and International Protection (2013-to be discussed in further detail below), non-European refugees are granted a limited form of protection-so-called conditional refugee status-which allows them to stay in Turkey until a longterm place of settlement outside Turkey is found for them or until they can return. ${ }^{67}$

The crisis in Syria began in March 2011 as a peaceful protest against the regime of Syrian president Bashar al-Assad. However, the conflict escalated and by mid-2012 larger numbers of people fled the war to neighbouring countries. In May 2011 the first camps for Syrian refugees opened in Turkey. ${ }^{68}$ As of July 2017, there were over three million Syrian refugees in Turkey, and Turkey is currently the world's largest refugee-hosting country. ${ }^{69}$

In October 2011 the Turkish government introduced a temporary protection regime for all Syrians, Palestinian refugees, and stateless persons living in Syria who arrived in Turkey to seek refuge..$^{\circ}$ At this time, there were few details given about the nature of this temporary protection regime. For the most part, particularly initially, Turkey maintained an open-door policy with Syria, ${ }^{71}$ and thus many refugees fleeing Syria were able to enter into Turkey. The Turkish government took responsibility for the refugees, and the UNHCR provided services through the Turkish government-it was not allowed to undertake RSD because Turkey did not consider them "refugees" within the meaning of the 1951 Convention..$^{72}$ As more refugees arrived in Turkey, the Turkish government clarified the temporary protection regime and adopted formal regulation regarding refugees from Syria.

Law No. 6458 on Foreigners and International Protection of April 2013, states in article 91 under provisional article 1,

The citizens of the Syrian Arab Republic, stateless persons and refugees who have arrived at or crossed our borders coming from Syrian Arab Republic as part of a mass influx or individually for temporary protection purposes due to the events that have taken place in Syrian Arab Republic since 28 April 2011 shall be covered under temporary protection, even if they have filed an application for international protection. Individual applications for international protection shall not be processed during the implementation of temporary protection. ${ }^{73}$

This article also states, "Proceedings to be followed on reception into, stay in, rights and obligations in, exit from Turkey of such persons, along with measures to be taken against mass movements ... shall be governed by a regulation to be issued by the Council of Ministers." 74

In October 2014 the Turkish Council of Ministers adopted Regulation No. 29153 on temporary protection (the 2014 Regulation), which established "rules on registration and documentation procedures to be followed by temporarily protected persons, introduces a clear right to stay in Turkey until the temporary protection regime is over, and clarifies the set of rights and entitlements for the temporary protection beneficiaries." 75 According to article 10 of the 2014 Regulation, the Council of Ministers has the power to set a maximum time limit, but the regulation does not oblige them to do so. ${ }^{76}$ Article 38 of the 2014 Regulations provides temporary protection beneficiaries with access to shelter, food, health care, social assistance, education, and other services within temporary accommodation centres. ${ }^{77}$ However, non-camp refugees constitute almost 88 per cent of all the Syrian refugee population in Turkey, and there are reports that their access to these services is uneven. ${ }^{78}$

More than seven years into the crisis, there are some downfalls to and gaps in the 2014 Regulation. There is no explicit right to work, education, and social assistance for Syrians. ${ }^{79}$ Even with education, accessing schools can be more difficult because "the everyday realities of Syrian families in the face of poverty, where families cannot afford to clothe and pay for the transportation costs of sending their children to school." 80

Moreover, while Syrians who hold temporary protection beneficiary identity cards can apply for work permits under article 29(2), the access was to be determined later by the Council of Ministers. ${ }^{81}$ In this regard, two regulations were passed in 2016; the first, on 15 January 2016, gave registered Syrian refugees living in Turkey for more than six months the ability to apply for a work permit in the province where they first registered. The limitations of this law are that that the individual's work permit is tied to a single place of employment, making it difficult or inconvenient to transfer, and that the proportion of refugees and asylum seekers cannot exceed 10 per cent of a company's workforce. ${ }^{82}$ The second regulation, passed on 26 April 2016, gave the prospective employer the responsibility of submitting applications for work permits to the Ministry of Labour and Social Security. ${ }^{83}$ However, it appears that many employers are unwilling 
to comply with the regulations, which require them to pay the Syrian employees minimum wage; for some, the reason for employing Syrian refugees is precisely because they are easily exploited. ${ }^{84}$ While Turkish law imposes heavy fines for employing individuals without work permits, employers seem not to be discouraged. ${ }^{85}$ The longer the Syrian conflict continues, the more likely it will be that illegal labour will increase, unless the Turkish government finds a way to ensure that employers apply for work permits for the refugees. In the meantime, beneficiaries of temporary protection are more susceptible to exploitation and trafficking, as well as resentment from the host population, since employers have a "cheaper" option.

More refugees are pouring into Turkey, with greater numbers making the dangerous journey to Europe by boat; indeed, in 2015 alone, more than one million people arrived in the $\mathrm{EU}$, around 885,000 of them through Greece. ${ }^{86}$ The city of İzmir has become a transit city for those wanting to cross into Europe via Greece. In 2015 over 91,00o people were apprehended or rescued at sea by Turkish authorities in the Aegean Sea. ${ }^{87}$ To respond to these growing numbers, in November 2015 the EU and Turkey agreed on the EU-Turkey Joint Action Plan, which was followed by the EU-Turkey statement (also known as the EU-Turkey Deal) on 8 March 2016. The EU-Turkey Deal stipulated that all new irregular migrants crossing from Turkey to the Greek islands as of 20 March 2016 would be returned to Turkey, and the Eu would give Turkey $€_{3}$ billion to support Syrians in Turkey, as well as give them legal pathways to seek asylum in Europe. Refugees who managed to arrive at one of the Greek islands would be put under an admissibility procedure to determine whether Turkey is a safe country for them to be returned to; if it is deemed that Turkey is safe, then the refugees are returned, and if it is deemed that Turkey is not safe, then the asylum seeker must proceed with the eligibility requirements in order to qualify for protection. There are exceptions made for vulnerable categories of people, who are permitted to make their asylum claim in Greece without going through the admissibility interview. Indeed, it seems that the EU-Turkey Deal has helped to curb the flow of refugees into Europe; according to the European Commission, from 10,000 in one day in October 2015 to an average of around 43 per day in March 2017, while the number of deaths at sea decreased from 1,145 in the year before the EU-Turkey Deal to 80 in the year that followed. ${ }^{88}$ The Greek Council of State decided on 22 September 2017 that Turkey is a safe third country for two Syrians (cases 2348/2017 and 2348/2017).

\section{What Works?}

As can be seen, temporary protection of refugees as a formal status gained prominence during the 1990 as a response to forced migration, particularly due to the Bosnian and Kosovar refugee crises. ${ }^{89}$ However, temporary protection has been criticized as an attempt to de-legalize refugee protection by placing it within the executive power of the state, rather than allowing it to remain subject to legal interpretation of the 1951 Refugee Convention. ${ }^{90}$ Yet even refugee advocates recognize that informal protection can serve humanitarian objectives $^{91}$ and enables persons who fall outside the convention's definition to receive international protection. Thus, in asking, "What works?", we need to be clear about the objectives of temporary protection for the purposes of this article: namely the protection of large influxes of refugees until they can be safe to return, guaranteeing their human rights, as well as increasing protection and integration in cases of protracted conflicts to ensure that refugees can live in dignity.

\section{Short-Term Humanitarian Aid and Support}

In the Gulf case, the refugees were given shelter in private accommodation, as well as access to education. The Kuwaiti refugees, rarely discussed in those terms in academic literature, were perhaps the most "privileged" of the cases discussed in this article, with a wealthy government that could support them in exile, and a relatively swift return. Other factors contributed to the "success" of these temporary protection measures: the wealth of neighbouring countries, the shared cultural and linguistic ties, the relatively small numbers of refugees, the lack of historical grievances between Gulf states (at the time), and the support of Gulf countries for Kuwait and its people during the war. In this case, the circumstances were quite exceptional and difficult to replicate. Nevertheless, providing Kuwaitis with access to neighbouring states, shelter, and a stipend enabled them to live relatively normally in the months of the war. After seven months, their country was liberated, and it was safe for them to return.

In Germany many Bosnians lived in collective accommodation centres, while many others were privately accommodated. Recipients of temporary protection were allowed assistance in kind with a modest monthly stipend. For the first three months, while they were staying in receptions centres, access to schools for children of asylum seekers was not guaranteed in all federal states. However, after three months, children of those receiving temporary protection had access to primary and secondary schooling. For the short terma few months-these measures may be seen to be suited to large numbers of people fleeing and ensure that the national refugee system is not overwhelmed.

In the first year of the Syrian war, Turkey's measures were commendable and were in compliance with minimum international standards: no forcible return, no individual status determination, as well as accommodation and provision 
of basic services in camps. The camps were also deemed of acceptable standard; Turkey's Ministry of Education opened schools within the camps, and those living in the camps were given access to health care in Turkish hospitals..$^{92}$

While the examples above show that these countries were prepared and able to provide truly "temporary" and short-term protection, the real problems emerge when the refugee crisis lasts several years, with increasing numbers of people seeking refuge.

\section{Integration and Access to Employment and Services after Prolonged Stay}

Some scholars suggest that where refugees enjoy rights and expect to be able to obtain citizenship rights, irrespective of whether or not they are naturalized, they tend to remain in host countries "regardless of whether the factors that prompt displacement are eliminated." 93 This seems, of course, to be contrary to the term temporary protection and not what many host countries have in mind. However, this is not necessarily true, nor, even if it is true for some cases, does it need to be negative.

For Kuwaiti refugees, by virtue of being GCC citizens, they were already "integrated" in that they had the freedom to work if they wanted to and were given free access to government schools and other government services. While most Kuwaitis did not get jobs, had the war continued for another year or two, it can be assumed that they would have had to, as it is difficult to know whether Kuwaiti refugees would have continued to receive assistance from supporting governments (the host government as well as their government-in-exile) had the war been prolonged. The main point to consider is that close to all Kuwaiti refugees returned after the war, despite being well integrated into the host societies. Indeed the factor that may most influence the decision of refugees not to return to their homes of origin is economic consideration, and whether they would be able to survive and thrive once they return. ${ }^{94}$ On 20 April 1991 the first post-liberation government was formed with the objective of "restoring daily life and developing a program leading up to national assembly elections scheduled for 5 October 1992." 95 This, as well as high nationalist feelings, ensured that most Kuwaitis returned home.

Of course some conflicts remain protracted, and recipients of temporary protection may remain for years in the host countries. In the case of Germany, it was the only EU country in 1997 that forcibly returned persons to areas where they may form ethnic minorities, in opposition to UNHCR guidelines, meaning that return was often under conditions in which security could not be guaranteed. ${ }^{96}$ The types of documents the Bosnian refugees had determined their access to services in Germany. The majority of Bosnians were not provided access to language lessons, family unification, or travel documents; work permits were given only for a specific job for which no Germans or EU citizens were available. In the rest of Europe, the integration solution for Bosnians was mainly contingent on their positive impact upon labour markets and the relative ease of their cultural assimilation. ${ }^{97}$ The countries naturalizing Bosnians considered those who had "regular employment, or private accommodation, and/or had not been convicted of a crime in the host country." 98

Recipients of temporary protection, if given legal channels to do so, can become integrated, productive, and selfreliant. Indeed, without "a comprehensive integration policy including an employment strategy, the risk for social exclusion and rising xenophobia [increases] in the host society." 99 As the Syrian crisis enters its seventh year and refugees' stay in Turkey is prolonged, discontent is increasing within Turkish society. ${ }^{100}$ One of the reasons, as mentioned above, is their provision of cheap labour, and the barriers to accessing the labour market legally (such as requiring employers to apply for a work permit). Another reason, however, is their large number, which creates fear among the local population that the refugees are a burden on national resources, and that they would have to compete with them for jobs. One suggested solution to this problem is to give the government the right to regulate "the competition Syrians may create in the labor market," ${ }^{101}$ which is what the new employment laws have set out to do. This is a good first step but must be enforced in order to ensure that Syrians are not exploited.

\section{Long-term Cooperation and Shared Responsibility}

The previous points speak to the short and medium term of a conflict, and some positive and negative examples of temporary protection. In order to ensure that temporary protection of refugees is truly successful, I suggest that there must be regional as well as international harmonization of longterm outlooks when the temporary turns into a protracted situation. ${ }^{102}$ When a situation that was meant to be "temporary" is prolonged, states may have to consider long-term or even permanent stay through citizenship or some form of permanent residence. ${ }^{103}$ States are apprehensive about this possibility, particularly because during mass influxes of people, some states shoulder more responsibility than others, with resulting implications for national resources and capacity. With Bosnian refugees in Europe, three countries-Germany (59 per cent), Austria, and Sweden-received 89 per cent of all Bosnians. ${ }^{104}$ In the Syrian case, as of June 2017, out of an approximate 5 million registered Syrian refugees, around 3.5 million are in Turkey (6o per cent), while almost 1 million are in Lebanon (20 per cent) - meaning that 80 per cent of refugees are in just two countries-and over 650,000 in Jordan, almost 250,000 in Iraq, and almost 130,000 in Egypt, ${ }^{105}$ whose capacities are already stretched. During the 
Bosnian crisis, a reason why the UNHCR accepted the compromise of "temporary protection" was that it was believed that it would encourage more EU countries to accept those who were fleeing ethnic cleansing. ${ }^{106}$ However, this proved not to be the case and may explain why Germany is the only country to have embarked upon mandatory repatriation.

In the Gulf it is unclear whether Kuwaiti refugees would have been allowed to naturalize; while Gulf states are notorious for their restrictive nationality laws, ${ }^{107}$ Kuwaiti citizens could have been an exception, as they also benefit from preferential treatment as Gulf nationals. At the same time, Gulf (and most Arab) states in general have refused to naturalize Palestinian refugees on the premise that they would lose their right to return, so Gulf countries could have taken the same route regarding Kuwaiti refugees, fearing that naturalizing them would mean that they would not return. At this point, however, this is mere speculation. The important point is that the Kuwaiti refugees had the main freedoms that allow for successful integration: freedom of movement, work, and residence; the right of ownership, inheritance, and bequest; and the freedom of exercising economic activity. ${ }^{108}$ Their smaller numbers in each of the Gulf states also means that their permanent integration would have been easier; indeed, the largest country in the GCC-Saudi-with extensive resources had the largest number of Kuwaiti refugees $(200,000)$, followed by the UAE, followed by the smaller GCC states. It appears that the numbers of refugees in each state were proportional to that state's size and population. However, the Kuwaiti refugees in the Gulf are an exception because of all the points mentioned previously (wealth, cooperation, cultural and linguistic ties, etc), so the relative "success" of the measures taken at the time cannot be used as a blanket standard to apply. However, the freedoms mentioned are indeed useful as a model for incremental integration.

One suggestion would be that, in the event of a large refugee crisis that has continued for over a year, the UN or regional bodies (such as the $\mathrm{EU}$ ) directly tackle the issue of shared responsibility, ensuring that a group of countries takes in refugees under temporary protection proportional to their population and resources. As within their sovereign right, states may decide whether or not to eventually naturalize the refugees, but the manageable size of the refugee population would make it easier for those states to extend certain rights necessary for to integrate refugees and avoid resentment among the local population. This has been the case for the European countries that eventually naturalized Bosnian refugees. The problem Turkey is facing now, for example, is that they host the vast majority of all Syrian refugees. Language barriers, the large number of urban refugees, and restrictive employment laws, which lead to illegal labour, also cause resentment with the host population, and so the government must take extra measures to balance increasing xenophobia with the needs of a large number of refugees. Turkey amended its citizenship law in April 2018, making some Syrians eligible for citizenship (for example, one condition is that the applicant should be residing in Turkey for at least five years, which most Syrian refugees have been, yet they should also "have an income or profession to provide for his own livelihood and those of his/her dependents in Turkey," which most do not). ${ }^{109}$

Yet with a system in place to more equitably manage the proportion of refugees taken in host states, the hope is that it would be easier to extend rights to recipients of temporary protection. Getting countries to agree to numbers would be a great feat, and the reality is that many countries avoid accepting large numbers of temporary refugees unless they are forced to by circumstance. However, many asylum seekers are using Turkey as a transit point to go to the European Union; indeed, the EU-Turkey Deal was meant to curb this by supplying Turkey with monetary resources to better manage the refugees, as well as allow these refugees a legal route to EU asylum via resettlement. ${ }^{110}$ In theory, this is a good step, although it should be mentioned that there is much criticism of the EU-Turkey Deal and it still keeps most refugees in Turkey. ${ }^{111}$ The point is that states must negotiate hosting refugees when conflicts are prolonged, to more equitably share responsibility for refugees. Otherwise, refugees themselves will attempt to move on from countries of first arrival, as they have been, resulting in the rise of smuggling rings and exposure to further danger. ${ }^{112}$

\section{Conclusion}

Temporary protection seems to be a widely acceptable solution by many states for large influxes of refugees, particularly when it is difficult to undertake individual RSD and when states are reluctant to open their doors to large numbers of refugees. While many temporary protection measures are sufficient when the crisis is truly temporary and short term, problems arise when the causes of displacement are more extended. Thus there is something to learn from the positive aspects of past temporary protection regimes in order to apply today.

The example of Kuwaiti refugees in the Gulf, as well as Bosnian refugees in European countries other than Germany, showed that where numbers are manageable and refugees are given legal channels to work, this benefits the host community as well as the refugees. The problem that Turkey faces now is the high number of refugees and the issue of accessible and legal work. A possible solution is greater responsibility sharing between states for refugees so that no single state is over-capacitated, making the numbers more manageable and thereby enabling host governments to provide an incrementally more favourable situation for refugees. 
In the face of wars that have no end in sight, this solution ensures that refugees are protected and neighbouring states are not left to absorb large numbers of refugees and exhausting national resources.

\section{Notes}

1 UNHCR, "Protection of Refugees in Mass Influx Situations: Overall Protection Framework," Global Consultations on International Protection, 19 February 2001, paragraphs 2-8.

2 Patricia Tuitt, "Rethinking the Refugee Concept," in Refugee Rights and Realities: Evolving International Concepts and Regime (Cambridge: Cambridge University Press, 1999), 111.

3 League of Nations, Convention Concerning the Status of Refugees Coming From Germany," League of Nations Treaty Series, vol. 192, no. 4461, 10 February 1938, 59.

4 These grounds are race, religion, nationality, membership in a social group, or political opinion. See article $1 \mathrm{~A}$ (2), Convention Relating to the Status of Refugees, 28 July 1951, United Nations, Treaty Series, 189:137.

5 Dennis Gallagher, "The Evolution of the International Refugee System," International Migration Review 23, no. 3 (1989): 582.

6 Gallagher, "Evolution of the International Refugee System," 595.

7 James C. Hathaway, "A Reconsideration of the Underlying Premise of Refugee Law," Harvard International Law Journal 31 (1990): 157 .

8 Article 1, Organization of African Unity (OAU), Convention Governing the Specific Aspects of Refugee Problems in Africa, 10 September 1969, 1001 UNTS 45.

9 J.O Moses Okello, "The 1969 OAU Convention and the Continuing Challenge for the African Union," Forced Migration Review (November 2014), http://www.fmreview.org/faith/ okello.html.

10 Joan Fitzpatrick, "Temporary Protection of Refugees: Elements of a Formalized Regime," American Journal of International Law 94, no. 2 (2000): 279.

11 Meltem Ineli-Ciger, Temporary Protection in Law and Practice, International Refugee Law (Leiden: Boston: Brill Nijhoff, 2018), 10:92-3.

12 James Hathaway, "Temporary Protection of Refugees: Threat or Solution?", in Perspective on Refugee Protection in South Africa (Pretoria: Lawyers for Human Rights, 2001), 41.

13 Khalid Koser and Richard Black, "Limits to Harmonization: The 'Temporary Protection' of Refugees in the European Union," International Migration 37, no. 3 (September 1999): 523, 531.

14 UNHCR, "Guidelines on Temporary Protection or Stay Arrangements," UNHCR Division of International Protection, February 2014, para. 11, 3.

15 Fitzpatrick, "Temporary Protection of Refugees," 280.
16 Koser and Black, "Limits to Harmonization," 531.

17 Matthew Albert, "Governance and Prima Facie Refugee Status Determination: Clarifying the Boundaries of Temporary Protection, Group Determination, and Mass Influx," Refugee Survey Quarterly 29, no. 1 (2010): 77.

18 UNHCR, "Guidelines on Temporary Protection or Stay Arrangements," para. 17, 5 .

19 Protection may be considered "temporary" or limited if an ad hoc arrangement was made for the refugees that would not be assumed to continue if the refugees were expected to stay permanently.

20 UN General Assembly Resolution 71/1, New York Declaration for Refugees and Migrants, 19 September 2016, A/ RES/71/1, para. 5 .

21 Meltem Ineli-Ciger, "A Temporary Protection Regime in Line with International Law: Utopia or Real Possibility?," International Community Law Review 18, no. 3-4 (2016): 289-94.

22 Labīb 'Abd al-Salām Qudsīyah, Al-Lājì̄un Al-Filasțīnīyūn Fì Al-'Irāq, Silsilat Dirāsāt 7 (Rām Allāh, Filasțīn: Markaz al-Lājiīn wa-al-Shatāt al-Filasţīnī [sHAML], 1997), 19-2o.

23 Some Gulf states temporarily adopted the Arab League's 1965 Protocol for the Treatment of Palestinians (the "Casablanca Protocol"). Bahrain, Qatar, Oman, and the United Arab Emirates joined the Arab League upon signing the protocol, while Kuwait signed the protocol with reservations. Saudi Arabia did not sign the protocol. However, following the Gulf War of 1990-1, the Arab League adopted resolution 5093, which left host states to regulate the status of Palestinians.

24 For example, human rights organizations have stated that Gulf countries have not taken in any Syrian refugees, while Saudi Arabia has claimed it has received 500,000 to 2.5 million Syrians; without regulations to specify their status, it is difficult to ascertain the true numbers. See Anhvinh Doanvo, "Western Media's Miscount of Saudi Arabia's Syrian Refugees," Huffington Post (blog), 23 September 2015, http://www.huffingtonpost.com/anhvinh-doanvo/ europes-crisis-refugees_b_8175924.html; Chaker Khazaal, "No, Arab Gulf Countries Are Not Taking in Refugees," Huffington Post (blog), 13 October 2015, http://www.huffingtonpost.com/chaker-khazaal/no-arab-gulf-countriesar_b_8280448.html. The UAE announced in September 2016 that it would welcome 15,000 Syrian refugees over five years. No plan has been announced, but the UNHCR confirmed that they were working closely with the UAE to help bring the refugees to the UAE. Sarwat Nasir, "UAE Is "Working Closely' with UN to Bring Home Refugees," Khaleej Times, 7 May 2017, http://www.khaleejtimes.com/nation/sharjah/ uae-is-working-closely-with-un-to-bring-home-refugees.

25 Most Palestinians were Jordanian citizens, although some stateless Palestinian from Gaza were stranded in Kuwait, unable to return to Egypt.

26 Ann M. Lesch, "No Refuge for Refugees: The Insecure Exile of Palestinians in Kuwait," in Exile and Return: 
Predicaments of Palestinians and Jews (Philadelphia: University of Pennsylvania Press, 2005), 171.

27 Judith Miller, "The World; Displaced in the Gulf War: 5 Million Refugees," New York Times, 16 June 1991, http:// www.nytimes.com/1991/o6/16/weekinreview/the-worlddisplaced-in-the-gulf-war-5-million-refugees.html.

28 Human Rights Watch, "Human Rights in Iraq and IraqiOccupied Kuwait: Testimony of Andrew Whitley, Middle East Watch before the House Foreign Affairs Committee," 8 January 1991, https://www.hrw.org/reports/1991/IRAQ91. htm.

29 Yahya Sadowski, "Arab Economies after the Gulf War: Power, Poverty, and Petrodollars," Middle East Report 170 (1991): 5; Kim Murphy, "Refugees from Kuwait Tell of Growing Panic," Los Angeles Times, 17 September 1990, http://articles. latimes.com/1990-09-17/news/mn-488_1_iraqi-soldiers.

30 There is no official breakdown of Kuwaiti refugees in the respective countries of refuge. It can be assumed that more Kuwaiti refugees arrived in the UAE between September and December 1990. See George D. Moffett, "Refugees Wait, and Hostages Return to us," Christian Science Monitor, 12 September 1990, https://www.csmonitor.com/1990/0912/ oexile.html.

31 Moffett, "Refugees Wait, and Hostages Return to us."

32 R.K. Ramazani, "Iran's Foreign Policy: Both North and South," Middle East Journal 46, no. 3 (1992): 400.

33 In May 1981 the Gulf Cooperation Council's "Unified Economic Agreement between the Countries of the Gulf Cooperation Council," chapter 2, article 8, notes that the member states shall agree on executive principles to ensure that each member state shall grant citizens of all member states the same treatment as is granted to its own citizens without any discrimination of differentiation in the following fields: (1) freedom of movement, work, and residence, (2) right of ownership, inheritance, and bequest, (3) freedom of exercising economic activity, (4) free movement of capital. In Zahra Babar, "Free Mobility within the Gulf Cooperation Council," Georgetown University School of Foreign Service in Qatar, Occasional Paper No. 8, 2011, 3n8.

34 Moffett, "Refugees Wait, and Hostages Return to us."

35 Moffett, "Refugees Wait, and Hostages Return to us."

36 Sadowski, "Arab Economies after the Gulf War," 7.

37 Mary Ann Tétreault, "Divided Communities of Memory: Diasporas Come Home," in Muslim Diaspora: Gender, Culture and Identity (Abingdon, uk: Routledge, 2007), 86.

38 Moffett, "Refugees Wait, and Hostages Return to us."

39 Peter W. Galbraith, "Refugees from War In Iraq," Migration Policy Institute no. 2 (February 2003): 3.

40 Tétreault, "Divided Communities of Memory," 93-5.

41 Full title: European Union Directive 2001/55/EC on Minimum Standards for Giving Temporary Protection in the Event of a Mass Influx of Displaced Persons and on Measures Promoting a Balance of Efforts between Member States in Receiving Such Persons and Bearing the Consequences, 20 July 2001.
42 Albert, "Governance and Prima Facie Refugee Status Determination," 78 .

43 Ineli-Cigar suggests that the reason for the lack of implementation is the fear of member states that the directive would become a pull factor for migrants seeking entry into the EU. See Meltem Ineli-Ciger, "Has the Temporary Protection Directive Become Obsolete? An Examination of the Directive and Its Lack of Implementation in View of the Recent Asylum Crisis in the Mediterranean," in Seeking Asylum in the European Union: Selected Protection Issues Raised by the Second Phase of the Common European Asylum System (Leiden: Brill, 2015), 225-46.

44 Koser and Black, "Limits to Harmonization," 522.

45 Fitzpatrick, "Temporary Protection of Refugees," 286.

46 Hathaway, "Temporary Protection of Refugees," 45. The UNHCR made two appeals to Western governments to provide such contingency places for Balkan refugees. See also Michael Pugh and Alex S. Cunliffe, "The UNHCR as Lead Agency in the Former Yugoslavia," Journal of Humanitarian Assistance, April 1996

47 Formal name: Operational Plan for Durable Solutions within the Framework of Annex 7 of the General Framework Agreement for Peace in Bosnia and Herzegovina and Related Regional Return and Repatriation Movements.

48 Simon Bagshaw, "Benchmarks or Deutschmarks: Determining the Criteria for the Repatriation of Refugees to Bosnia and Herzegovina," International Journal of Refugee Law 9, no. 4 (1997): 566-7.

49 Bagshaw, "Benchmarks or Deutschmarks," 567.

50 Koser and Black, "Limits to Harmonization," 524.

51 Gaim Kibreab, "Citizenship Rights and Repatriation of Refugees," International Migration Review 37, no. 1 (2003): 40-1.

52 Koser and Black, "Limits to Harmonization," 528.

53 Bagshaw, "Benchmarks or Deutschmarks," 590.

54 Koser and Black, "Limits to Harmonization," 528.

55 Humanitarian Issues Working Group, "Survey on the Implementation of Temporary Protection," 8 March 1995, http://www.refworld.org/docid/3ae6b330o.html.

56 Koser and Black, "Limits to Harmonization," 536.

57 Humanitarian Issues Working Group, "Survey on the Implementation of Temporary Protection."

58 At the time, this was equivalent to about Us $\$ 47$.

59 Holders of either permit enjoy standards at least equivalent to those applied to asylum seekers, and not recognized refugees. See Humanitarian Issues Working Group, "Survey on the Implementation of Temporary Protection."

6o Norway and Austria declared that repatriation would occur only voluntarily, while Sweden "stated that those Bosnians originating from areas where they would be in a minority would be able to remain in Sweden as refugees." Bagshaw, "Benchmarks or Deutschmarks," 590.

61 Koser and Black, "Limits to Harmonization," 528.

62 UNHCR, "Germany: UNHCR Urges Residency for Bosnians," 30 May 2000, http://www.unhcr.org/news/briefing 
/200o/5/3ae6b81d5b/germany-unhcr-urges-residency-bosnians.html.

63 Kibreab, "Citizenship Rights and Repatriation of Refugees," 42.

64 Bagshaw, "Benchmarks or Deutschmarks," 572-3.

65 Full name: Regulation No. 1994/6169 on the Procedures and Principles Related to Possible Population Movements and Aliens Arriving in Turkey Either as Individuals or in Groups Wishing to Seek Asylum Either from Turkey or Requesting Residence Permission in Order to Seek Asylum from Another Country, http://www.refworld.org/ docid/49746cc62.html.

66 Turkish Law No. 2510/1934 Settlement Act (Kanun No. 2510/1934 Iskan Kanunu), Turkish Republic Official Journal 2733 (repealed 26 September 2006).

67 Article 62(1), Law No. 6458 of 2013 on Foreigners and International Protection [Turkey], 4 April 2013, http://www.refworld.org/docid/5167fbb2o.html.

68 UNHCR, "Chronology of Syrias Displacement Crisis Fact Sheet," September 2013, http://www.unhcr.org/5245a72e6. pdf.

69 UNHCR, "Syria Regional Refugee Response," March 2017, http://data.unhcr.org/syrianrefugees/regional.php.

70 Meltem Ineli-Ciger, "Implications of the New Turkish Law on Foreigners and International Protection and Regulation No. 29153 on Temporary Protection for Syrians Seeking Protection in Turkey," Oxford Monitor of Forced Migration 4, no. 2 (2015): 28.

71 According to Amnesty International, there were some mass forced returns of Syrians by the Turkish security forces in early 2017, as well as reports of "unlawful pushbacks to Syria and cases of fatal and non-fatal shootings of people in need of protection by Turkish border guards." Amnesty International, "Turkey 2016/2017," 2017, https:// www.amnesty.org/en/countries/europe-and-central-asia/ turkey/report-turkey/.

72 Susan Akram et al., "Protecting Syrian Refugees: Laws, Policies, and Global Responsibility Sharing," Boston University School of Law 99 (2014), http://www-syst.bu.edu/law/ central/jd/programs/clinics/international-human-rights/ documents/FINALFullReport.pdf.

73 Turkey: Regulation No. 29153 on Temporary protection (October 2014).

74 Turkey: Regulation No. 29153.

75 Ineli-Ciger, "Temporary Protection for Syrians Seeking Protection in Turkey," 29.

76 Ineli-Ciger, "Temporary Protection, 31.

77 Ineli-Ciger, "Temporary Protection, 32.

78 Ayselin Yıldız and Elif Uzgören, "Limits to Temporary Protection: Non-Camp Syrian Refugees in İzmir, Turkey," Southeast European and Black Sea Studies 16, no. 2 (April 2, 2016): 197.

79 Ineli-Ciger, "Temporary Protection for Syrians Seeking Protection in Turkey," 32.
80 Feyzi Baban, Suzan Ilcan, and Kim Rygiel, "Syrian Refugees in Turkey: Pathways to Precarity, Differential Inclusion, and Negotiated Citizenship Rights," Journal of Ethnic and Migration Studies 43, no. 1 (2 January 2017): 50.

81 Ineli-Ciger, "Temporary Protection for Syrians Seeking Protection in Turkey," 33.

82 Republic of Turkey, Geçici Koruma Sağlanan Yabanciların Çalışma İzinlerine Dair Yönetmelik, Resmî Gazete 8375, 15 January 2016, available at http://www.resmigazete.gov.tr/ eskiler/2016/01/20160115-23.pdf.

83 Republic of Turkey, Uluslararası Koruma Başvuru Sahibi ve Uluslararası Koruma Statüsü Sahibi Kişilerin Çalışmasına Dair Yönetmelik, Resmî Gazete 29695, 26 April 2016, http:// www.resmigazete.gov.tr/eskiler/2016/04/20160426-1.htm

84 Patrick Kingsley, "Fewer Than 0.1\% of Syrians in Turkey in Line for Work Permits," Guardian, 11 April 2016, http:// www.theguardian.com/world/2016/apr/11/fewer-thano1-of-syrians-in-turkey-in-line-for-work-permits."

85 Sarah Bidinger, "Syrian Refugees and the Right to Work: Developing Temporary Protection in Turkey," Boston University International Law Journal 33 (2015): 235.

86 European Commission, "EU-Turkey Statement: One Year On," 17 March 2017, https://ec.europa.eu/homeaffairs/sites/homeaffairs/files/what-we-do/policies/ european-agenda-migration/background-information/ eu_turkey_statement_17032017_en.pdf.

87 Ylldız and Uzgören, "Limits to Temporary Protection," 201.

88 European Commission, "EU-Turkey Statement: One Year On."

89 Fitzpatrick, "Temporary Protection of Refugees," 279.

90 Koser and Black, "Limits to Harmonization," 529.

91 Fitzpatrick, "Temporary Protection of Refugees," 281.

92 Suna Gülfer Ihlamur-Öner, "Turkey's Refugee Regime Stretched to the Limit? The Case of Iraqi and Syrian Refugee Flows," Perceptions 18, no. 3 (2013): 204-5.

93 Kibreab, "Citizenship Rights and Repatriation of Refugees," 45.

94 Kibreab, "Citizenship Rights and Repatriation of Refugees," 37.

95 Sharon Stanton Russell and Muhammad Ali al-Ramadhan, "Kuwait's Migration Policy since the Gulf Crisis," International Journal of Middle East Studies 26, no. 4 (1994): 576.

96 Koser and Black, "Limits to Harmonization," 534.

97 Koser and Black, "Limits to Harmonization," 534.

98 Koser and Black, "Limits to Harmonization," 534.

99 Ylldiz and Uzgören, "Limits to Temporary Protection," 204.

100 Ylldiz and Uzgören, "Limits to Temporary Protection," 196.

101 Bidinger, "Syrian Refugees and the Right to Work," 244.

102 Indeed, the New York Declaration of September 2016 emphasized the importance of finding "long-term and sustainable solutions," as well as "a shared responsibility to manage large movements of refugees and migrants in a humane, sensitive, compassionate and people-centred manner (Resolution 71/1, New York Declaration for 
Refugees and Migrants, A/RES/71/13/24, 19 September 2016, paras 10-11).

103 The UNHCR's durable solutions are focused on citizenshipbased solutions. Katy Long, "Extending Protection? Labour Migration and Durable Solutions for Refugees," UNHCR, Research Paper No. 176, October 2009, 3. As the Syrian crisis surpasses its seventh year, Turkey is having to consider other, more long-term solutions: Ahmet İçduygu, "Syrian Refugees in Turkey: The Long Road Ahead," Migration Policy Institute, April 2015.

104 Koser and Black, "Limits to Harmonization," 533.

105 UNHCR, "Syrian Regional Refugee Response," http://data. unhcr.org/syrianrefugees/regional.php.

106 Koser and Black, "Limits to Harmonization," 533.

107 For example, articles 4 and 5 of Kuwait's Nationality Law, 1959, detail the ways in which non-Kuwaitis may acquire Kuwaiti citizenship, including living in the country for fifteen (for Arabs) to twenty years (non-Arabs), knowing the Arabic language, and possessing qualifications or rendering services needed in Kuwait. Under article 5(4), there is a yearly limit to how many non-citizens may be naturalized. However, only two thousand of the hundreds of thousands of Palestinians who had lived in Kuwait for decades prior to the 1990 Gulf War were naturalized. See Ann M. Lesch, "No Refuge for Refugees: The Insecure Exile of Palestinians in Kuwait," in Exile and Return: Predicaments of Palestinians and Jews (Philadelphia: University of Pennsylvania Press, 2005), 164. Under United Arab Emirates Federal Law No. 10 for 1975 Concerning Amendment of Certain Articles of the Nationality, and Passports Law No. 17 for 1972, article 8 , a non-citizen may be granted citizenship after living continuously in the country for not less than thirty years, among other conditions. Nevertheless, the president of the state may issue a Decree of Nationality to any person without complying with the terms of residence. However, the process is still unclear and there are no clear numbers for those who have been naturalized.

108 Zahra Babar, "Free Mobility within the Gulf Cooperation Council," Georgetown University School of Foreign Service in Qatar, Occasional Paper No. 8, 2011, 3 n8.

109 Turkish Citizenship Law (As Amended in 2018), Law No. 5901, April 2018, article 11 (b), (f), http://www.refworld. org/docid/4496bo6o4.html.

110 According to the EU Commission, 11,490 Syrian refugees had been resettled from Turkey to EU member states by December 2017. See Eu Commission, "The Commission's Contributions to the Leaders' Agenda," December 2017, https://ec.europa.eu/home-affairs/sites/homeaffairs/files/what-we-do/policies/european-agenda-migration/20171207_eu_turkey_statement_en.pdf. However, this constitutes only 15 per cent of the pledged number of Syrian resettlements. See Daily Sabah, "EU Resettled Only 15 Percent of Syrian Refugees It Pledged from Turkey, Report Says," 15 November 2017, https://www.dailysabah.com/euaffairs/2017/11/15/eu-resettled-only-15-percent-of-syrianrefugees-it-pledged-from-turkey-report-says.

111 Kondylia Gogou, "The EU-Turkey Deal: Europe's Year of Shame." Amnesty International, 20 March 2017, https://www.amnesty.org/en/latest/news/2017/03/ the-eu-turkey-deal-europes-year-of-shame/.

112 ввс News, "The Syrians Exploited by People-Smugglers in Turkey," 18 February 2018, http://www.bbc.com/news/ av/world-europe-34183454/migrant-crisis-the-syriansexploited-by-people-smugglers-in-turkey.

Jinan Bastaki is assistant professor of international law at UAE University. The author may be contacted at J.Bastaki@uaeu ac.ae. 